\section{The Constructive Imaginary}

\section{MICHAEL KARLBERG}

This special issue of the Journal marks a moment in a journey by a group of collaborators exploring the implications of an emerging concept with profound relevance to twenty-first century struggles for social justice. To understand the nature and purpose of this journey, it will help to know a little about the process that led us here. Before considering this process, however, it is important to note that the collection of essays in this journal represents only a small number of voices offering contributions at only one moment in a wider ongoing conversation. Many important voices and perspectives are absent from this collection, but not all things can be accomplished in any given setting. This collection of essays thus constitutes an invitation for all relevant voices to contribute, over time, to this expanding conversation.

This conversation began when, on 9 September 2007, the Universal House of Justice wrote a letter to Iranian Bahá'í students deprived of access to higher education in their country. In that letter, the House of Justice wrote:

Recent events call to mind heart-rending episodes in the history of the Faith, of cruel deceptions wrought against your forebears. It is only appropriate that you strive to transcend the opposition against you with that same constructive resilience that characterized their response to the duplicity of their detractors. Peering beyond the distress of the difficulties assailing them, those heroic souls attempted to translate the Teachings of the new Faith into actions of spiritual and social development. This, too, is your work. Their objective was to build, to strengthen, to refine the tissues of society wherever they might find themselves; and thus, they set up schools, equally educating girls and boys; introduced progressive principles; promoted the sciences; contributed significantly to diverse fields such as agriculture, health, and industry - all of which accrued to the benefit of the nation. You, too, seek to render service to your homeland and to contribute to a renewal of civilization. They responded to the inhumanity of their enemies with patience, calm, resignation, and contentment, choosing to meet deception with truthfulness and cruelty with good will towards all. You, too, demonstrate such noble qualities and, holding fast to these same principles, you belie the slander purveyed against your Faith, evoking the admiration of the fair-minded. (italics added)

The phrase first employed in this letter-constructive resilience - has since been employed by the Universal House of Justice in many other letters. Over 
time, it has captured the imagination of growing numbers of people because it is pregnant with meaning. This special issue of the Journal has emerged from conversations among one group of friends who have been exploring the meaning of this phrase, its relationship to other concepts in prevailing discourses on social change, and its broad relevance to the exigencies of the age.

In the reflections immediately below, the collaborative process that led to this special issue is shared, to underscore the value of this kind of collaborative inquiry. Some of the more salient insights that emerged from this process are also shared. In the latter regard, it should be noted that constructive resilience is neither an entirely new way of thinking about social change, nor is it a mere reiteration of previous conceptions of social change. Rather, aspects of constructive resilience have been explored by a range of previous thinkers, and have been embodied in a range of previous movements. What our collective inquiry has attempted to do is to bring into focus some of these prior conceptions and illustrations, and assemble them into a more coherent picture that expands our social imaginary.

The initial point of departure for my own study of constructive resilience traces back to my doctoral defense just over twenty years ago. My dissertation $^{1}$ examined the competitive logic

1 This dissertation was later published as Beyond the Culture of Contest: around which many Western liberal institutions and practices are constructed. According to this logic, human nature is essentially self-interested, so societies should be organized in competitive ways that harness all that selfish energy for the greater good. We see this logic expressed in partisan political systems, adversarial legal systems, capitalist economies, grade-based education systems, and even many contemporary forms of recreation and leisure.

In my dissertation, I analyzed the social and ecological consequences of this "culture of contest." My conclusion, in short, was that when most social institutions and practices are organized as contests of physical, political, or economic power, they privilege the short-term material interests of those who enter the contests with the most inherited power. This occurs at the expense of less powerful segments of society, and at the expense of future generations. The result is widespread social injustice and ecological ruin.

My dissertation also examined the way these unjust and ruinous outcomes cause many people to arise in protest. This is very understandable, and I share the underlying commitments to social justice and environmental stewardship that tend to animate such responses. Yet oppositional protests can inadvertently replicate and reinforce the underlying logic of the culture of contest. For instance, oppositional responses to

From Adversarialism to Mutualism in an Age of Interdependence (George Ronald, 2004). 
social injustice can reinforce assumptions about the inherently competitive or conflictual nature of human beings, along with assumptions about the inevitability of interest group competition in the social sphere-which constitute suppositional foundations of the culture of contest. Hence the paradox of protest in a culture of contest. ${ }^{2}$ The culture of contest gives rise to myriad injustices, which in turn give rise to oppositional dissent, which in turn reinforces the underlying logic of the culture of contest that gives rise to the injustices in the first place.

The way to transcend this paradox, I argued, is through a non-adversarial approach focused on the active construction of radically new institutions and practices organized around a more just logic. ${ }^{3}$ For instance, the

2 See Michael Karlberg, "The Paradox of Protest in a Culture of Contest."

3 A broadly similar argument was advanced in the early twentieth century by Gandhi, in his booklet titled Constructive Programme: Its Meaning and Place (1941). This argument was echoed by Carl Boggs' articulation of the concept prefigurative politics in his essay "Revolutionary Process, Political Strategy, and the Dilemma of Power"; and this concept of prefiguration was later taken up to some degree within various feminist and New Left movements. Such ideas have more recently been engaged by contemporary social change theorists such as Majken Jul Sørensen (see "Constructive Resistance: Conceptualizing and Mapping the Terrain,") and Karuna Mantena (see "Gandhi and the Means-Ends Question in Politics"). I engage this literature more directly in competitive electoral processes that emerged in Western liberal societies are inherently vulnerable to the corrupting influence of money, because electoral competitions are expensive to wage. This is a primary reason just and responsible governance has proven so elusive in Western liberal forms of democracy. One response to these endemic injustices is through protest. Another response is to begin constructing new democratic electoral forms that are free from competition and partisanship. ${ }^{4}$ To the extent that new social forms such as this can attract people away from prevailing ones, growing numbers of people can withdraw their participation from unjust social forms, which would eventually collapse of attrition. The culture of contest might thus be transcended, over time, through the construction of emancipatory social forms that supplant oppressive ones. In my dissertation, I offered examples that illustrate this dynamic.

After I made this point, one of my examiners countered, "That may work under some favorable conditions, but surely it's impossible under conditions of violent repression." As we were speaking, on the other side of the planet, the Bahá'ís of Iran were patiently advancing constructive processes of

the sixth chapter of my most recent book, Constructing Social Reality (see pages 180-188).

4 For an illustration of a proven electoral system that is entirely free from partisanship and competition, refer to $\mathrm{Mi}$ chael Karlberg, "Western Liberal Democracy as New World Order?" 
social transformation under conditions of violent repression. But this story had never been told through the lens I articulated in my dissertation. After my defense, I realized the need to do that.

As I began to write about this, I received a copy of the 9 September 2007 letter from the Universal House of Justice alluded to above. When I read the phrase constructive resilience, it crystalized in my mind precisely what I was trying to articulate. This phrase distills what it means to exercise transformative constructive agency under conditions of violent repression. So the phrase provided the organizing logic, and the title, for the article I was writing, which was subsequently published by the journal Peace \& Change.

Over the decade that followed, the Universal House of Justice used the phrase "constructive resilience" in other letters, and the concept was becoming the object of increasing attention. In 2017, I invited three friends whose scholarship is relevant to this concept to help organize a conference panel on the topic. Insights generated from that experience then informed several presentations at other conferences. Soon after, we planned an intensive weekend seminar on this concept, in Washington, D.C., with a dozen people from as many disciplines. Insights generated from the D.C. seminar informed further conference presentations and further conversations among the four of us.

On 4 February 2018, the Universal House of Justice wrote a letter to an individual about the ongoing challenge of racism in the United States. In that letter, the House of Justice expressed its hope

that those friends in the United States who resolve to renew their commitment to uprooting racism and laying the basis for a society that reflects interracial harmony can draw insight and inspiration from the unwavering resolve of the Bahá'ís in Iran. The messages written to the friends there in recent years, most of which have been translated into English and are publicly available, are instructive in this regard. For almost two centuries, and particularly the last four decades of relentless oppression, the Bahá'ís in Iran have remained forward-looking, dynamic, vibrant, and committed to serving Iranian society. They have refused to allow apprehension and anxiety to take hold or let any calamity perturb their hearts. They have drawn on the highest reservoirs of solidarity and collaboration and responded to oppression with constructive resilience, eschewing despair, surrender, resentment, and hate and transcending mere survival, to transform conditions of ignorance and prejudice and win the respect and collaboration of their fair-minded countrymen. Those believers in the United States who have labored so persistently to promote race unity, especially the African 
American friends, should appreciate in their own efforts over the years the same expression of constructive resilience, born of their great love for Bahá'u'lláh, and see in the recent turmoil opportunity rather than obstacle.

In the months following the arrival of this letter, the four friends alluded to above organized another seminar, held at the Highlander Research and Education Center in Appalachian Tennessee. Of the thirty participants who attended this seminar, the majority were African American, and the preceding passage was one of the focal points of our discussions. How can the constructive resilience of African Americans be articulated in ways that illuminate this powerful concept and illustrate its universal relevance? And where can we see other expressions of constructive resilience that further illuminate our understanding?

Immediately following the Highlander seminar, a workshop was offered in Atlanta at the annual conference of the Association for Bahá'í Studies, and approximately one hundred people attended. Some months later, another weekend gathering was held in Washington, D.C., with nine participants who had attended the previous D.C. or Highlander seminars and had expressed an interest in further engagement. That latter gathering in D.C. led to other academic presentations, along with the development of two university courses. Those same nine participants were also invited to serve on a nine-person panel for a plenary audience at the 2019 annual conference of the Association for Bahá'í Studies in Ottawa. It is those nine panelists who are the contributors to this special issue of the Journal.

The process alluded to above was a journey of mutual learning characterized by ongoing consultative inquiry, the testing of ideas in diverse spaces with diverse groups, reflection on experience, and refinement of language, concepts, and approaches. Of course, this conversation has not yet widened enough to embrace all relevant voices and perspectives. For instance, Indigenous voices will further illuminate the concept of constructive resilience in powerful ways. Nonetheless, this initial conversation has already carried its participants to a place at which no individual, journeying alone, could have arrived.

The essays collected here provide an opportunity to share a range of insights and reflections that have arisen, so far, on this path. By sharing these, we hope to inspire others to contribute further on this path of learning.

In sharing our initial insights, we've adopted a less formal, less academic style than is typical of academic journals. We've come to appreciate that it's rarely possible to "persuade" people of the value of constructive resilience through formal academic arguments. Though constructive resilience is an eminently rational concept, recognizing this requires a degree of intuition and inspiration. Constructive resilience speaks as much to the heart as the intellect. 
In keeping with this approach, I'm also dispensing, in this introductory essay, with the convention of summarizing each subsequent essay. The essays speak for themselves. Instead, I was asked by my peers to share some of my personal insights into constructive resilience, which have emerged along this path of learning.

For me, the concept of constructive resilience expands what social theorists call our "social imaginary" - our ability to imagine and enact new possibilities in the pursuit of social change. Imagination is a way of knowing. Our imaginations are informed, in part, by the stories we hear, including stories about who we are and how we got here.

At my doctoral defense, my examiner had never heard the story I later learned to tell about the Bahá'ís in Iran. Nor, it seems, had she heard any other stories of radical constructive agency coupled with resilience under conditions of violent repression. So, those possibilities lay outside the boundaries of her social imaginary.

Stories of social change have seldom been told in ways that bring constructive resilience into focus. Consider the many stories that tend to circulate about violent insurrections. Think, for instance, of the American and French revolutions, the Haitian revolution, or the Bolshevik and Maoist revolutions. We also hear many stories of nonviolent resistance. Think, for instance, of the struggle for independence in India, or the U.S. civil rights movement, or the Arab Spring.

Though the means of struggle differ between the first and second set of stories, the storylines are similar in important ways. In both sets of stories, a population that considers itself oppressed in some way engages its adversary directly in a confrontation leading to victory or defeat. Such stories have shaped our social imaginary when it comes to how people can struggle for change. This does not mean the substance of these stories is imaginary. They reflect the experiences of countless revolutionaries and activists, many of whom deserve our respect and admiration. But these dominant narratives displace other stories we could tell about other ways people have struggled for social change, thereby limiting our conception of what such struggles have looked like in the past and what they might look like in the future.

To understand the implications, it helps to contrast constructive forms of agency with contentious forms of agency-a distinction that other theorists of social change have also made. ${ }^{5}$ In the simplest terms, constructive agency is focused on building a more just social order. Contentious agency is focused on disrupting or dismantling an unjust social order. Both forms of agency can be motivated by commitments to social justice and by the corresponding

5 See, for instance, Sean Chabot and Stellan Vintagen, "Decolonizing Civil Resistance." 
pursuit of social change. But the means by which these ends are pursued differ.

The distinction between constructive agency and contentious agency need not be laden with value judgments. "Constructive" is not a synonym for "good" in this context and "contentious" is not a synonym for "bad." Both forms of agency may be needed in the broader scheme of things. Yet, this distinction enables us to notice forms of struggle that otherwise go unnoticed; to see protagonists who otherwise go unseen; to tell stories that otherwise go untold; to imagine futures that otherwise go unpursued.

For instance, the story I learned in school about the struggle for racial justice in the United States is the story of nonviolent protests and civil disobedience that culminated in the 1960s. It's a remarkable story that needs to be told, with countless heroes who deserve our admiration. More recently, the Movement for Black Lives is being told as the next chapter in this story of nonviolent resistance, with a new generation of heroes who clearly deserve our admiration.

While these stories need to be told, so too do the stories of countless African Americans who have struggled in other ways, for many generations, to construct elements of a more just social order. Those elements include schools and colleges, churches and hospitals, businesses and banks, economic cooperatives and associations of mutual aid, along with entirely new patterns of community life, new cultural forms, and new artistic expressions - all of which value Black lives. These endeavors have entailed heroic struggle under the most oppressive conditions, and these protagonists have contributed as much to the empowerment of African Americans as have contentious campaigns of nonviolent resistance. Indeed, these constructive struggles endowed the African American community with many of the material, social, and organizational resources that made campaigns of nonviolent resistance possible. ${ }^{6}$

Likewise, the stories about Indigenous struggles for justice that tend to circulate most widely on this continent tend to be stories such as the armed standoff of American Indian Movement activists at Wounded Knee, South Dakota, in 1973; or the armed standoff of Mohawk activists in Oka, Quebec, in 1990; or nonviolent protests against oil pipeline construction through Indigenous lands in North Dakota and British Columbia in recent years. In contrast, stories rarely circulate about the many ways Indigenous Nations across the continent are, at various paces, constructing new systems of governance, law, education, health care, and natural resource management. ${ }^{7}$ In many

6 For two excellent examples of recent scholarship on African American constructive agency, see Jessica Gordon Nembhard, Collective Courage: A History of African American Cooperative Economic Thought and Practice; and Monica White, Freedom Farmers: Agricultural Resistance and the Black Freedom Movement.

7 Refer, for example, to Jody Wilson-Raybould, From Where I Stand: Rebuilding Indigenous Nations for a Stronger Canada; Paul Boyer, Capturing 
cases, these constructive and resilient expressions of collective agency are based on spiritual principles and traditional practices that were assaulted under colonialism, survived, and are now being adapted to new social conditions.

In sum, stories of constructive resilience-among Indigenous peoples, within the African diaspora, and among many other marginalized populations have been widely ignored until quite recently. Stories of this nature now need to be widely told, to enrich our understand of the past and present, and to expand the horizon of possibility in the future.

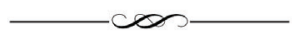

One insight we gain from such stories is that radical constructive agency in the face of oppression, just like contentious agency in the face of oppression, is frequently met by acute acts of violent repression. This should not be surprising. When people work to construct elements of a more just social order, those who benefit from the old order will notice. Among those who benefit from the status quo, remarkably, some will experience a moral awakening and support the cause of justice. Others will attempt to defend the status quo by repressing the struggle for change- - even when that struggle is pursued through entirely constructive means. In the face of such repression, resilience is

Education: Envisioning and Building the First Tribal Colleges; and Clint Carroll, Roots of Our Renewal: Ethnobotany and Cherokee Environmental Governance. an essential characteristic of sustained movements for social change. ${ }^{8}$

The constructive struggle of African Americans has repeatedly encountered such repression, as in the 1929 destruction of the prosperous Greenwood district in Tulsa, Oklahoma, and the massacre of its residents; or the destruction, two years later, of the prosperous town of Rosewood, Florida, and the massacre of its residents. More broadly, the resurgence of organized racism following the brief period of postbellum Reconstruction - a resurgence that included the rise of the $\mathrm{Ku}$ Klux Klan, the systematic disenfranchisement of Black voters, the passing of Jim Crow segregation laws, and the spread of lynching as a form of intimidation and social control-is an expression of this same dynamic.

When we examine, in this context, the constructive agency of the African American community, we can appreciate the profound resilience that community has shown over many generations. And as we do this, we can begin to seek out, recognize, or listen to other expressions of constructive resilience throughout history. Think, for instance, of the earliest Christian communities. As those communities focused on the construction of radically new, and more just, patterns of community life, they experienced brutal repression that was sustained for generations. In the face of such repression, their radical

8 For a discussion of resilience in nonviolent movements, see Kurt Schock, "The Practice and Study of Civil Resistance." 
constructive agency required powerful forms of resilience.

The story of the Bahá'ís in Iran, alluded to above, is another story of radical constructive agency and resilience that expands our social imaginary. It also invites us to consider where this constructive resilience comes from and what sustains it.

In this regard, Bahá'ís believe that recognition of the oneness of humanity is the primary spiritual and social challenge of this age and that justice must become the central organizing principle of a new social order derived from this recognition. Toward this end, Bahá'ís are committed to a twofold process of social change that includes the transformation of hearts and minds as well as the transformation of social norms and structures. They seek coherence between the means and ends of social change. They adopt a long-term perspective on change which calls for perseverance in a multi-generational struggle. They have faith in humanity's long-term capacity for justice. They employ a conception of power rooted in capacity building and focused on the application of spiritual principles to systematic processes of social transformation. They recognize that efforts to pursue meaningful social change will often be met by hostility and repression, and they accept that the pursuit of change thus requires sacrifice and resilience.

For instance, the Bahá'í community has been constructing a radical new form of governance by which it organizes its affairs through elected assemblies at local, national, and international levels. Bahá'í elections, in which voters have true freedom of choice, are entirely free of competition and its trappings of partisanship, money, ego, and self-interest. In Iran, women and men have served side by side on elected assemblies despite cultural prohibitions against such a practice, even as Blacks and Whites did in the U.S. South under Jim Crow segregation or in South Africa under apartheid, and as members of all castes do in cultures that perpetuate the caste system. This administrative order has frequently been attacked, and it has been temporarily dismantled by some repressive governments, including the current Iranian regime. Nonetheless, globally, the project of constructing a more just and viable model of governance continues undeterred. And when conditions change in Iran, which they eventually will, Bahá'ís will resume this aspect of their constructive work in that country. In the meantime, in Iran, Bahá'ís continue to channel their energies into other aspects of their constructive work.

Or consider the experience that prompted the 2007 letter from the Universal House of Justice quoted near the beginning of this essay. In recent decades, Bahá'ís have been denied access to higher education in Iran as part of the current regime's policy to block the progress of the community. In response, Bahá'ís constructed a decentralized university, the Bahá'í Institute for Higher Education (BIHE), 
in Bahá'í homes and offices across the country. BIHE now offers over one thousand distinct courses within five associate degree programs, eighteen baccalaureate degree programs, and fifteen graduate degree programs ranging across the arts and sciences. Faculty, staff, and students are occasionally arrested and imprisoned, and university materials are confiscated in raids. But the Iranian regime has been unable to destroy BIHE because of its decentralized and resilient nature. The regime is also unable to marshal any moral or legal argument in support of its efforts to destroy the university because of BIHE's purely peaceful and constructive nature. This is yet another expression of constructive resilience.

These stories are recounted not to valorize the struggles of any given people relative to the struggles of others, but to bring to light new insights in ways that expand our social imaginary. Another of these insights emerges as we return to a comparison of constructive and contentious agency.

Contentious nonviolent tactics, such as civil disobedience in the face of unjust laws, are intended, in part, to set up a moral dilemma within a population. In the face of the dilemma, those who benefit from unjust laws must choose to either support or repress the movement for justice. When repression occurs, it often attracts the moral sympathies and support of previously complacent bystanders and third parties, while galvanizing the will of the oppressed to advance the struggle. This is a well-understood principle in the theory and practice of nonviolent social change, purposefully applied in campaigns of civil disobedience. ${ }^{9}$

Radical constructive struggles, on the other hand, don't seek to publicly provoke moral dilemmas of this kind. Yet similar outcomes can still result. When constructive struggles are met with repression, this too can attract the moral sympathies and support of previously complacent bystanders and third parties while galvanizing the will of those engaged in the struggle.

This principle is illustrated clearly by the Bahá'í community in Iran, which has encountered a genocidal campaign of repression from its inception, yet has continued to grow and advance in a resilient manner, giving rise to a global movement attracting the support of an ever-expanding cross-section of humanity now engaged in radical constructive work in every country.

Every wave of repression Bahá'ís have encountered in Iran has tended to increase awareness of, sympathy for, and interest in the Bahá'í Causeboth within Iran and around the world. For instance, in recent decades, as the Iranian authorities have implemented increasingly desperate measures to repress Bahá'ís, the wider population of Iran has become increasingly willing to defend Bahá'ís and increasingly attracted to the Faith. Indeed, far more

9 See, for instance, Gene Sharp, The Politics of Nonviolent Action. 
Iranians are now identifying as Bahá'ís than at any time in the history of that country, even though becoming a Bahá'í is now considered by the regime to be a crime of apostacy punishable by death. ${ }^{10}$ As a result of these dynamics, many Bahá'ís in Iran have been galvanized to new heights of consecrated action.

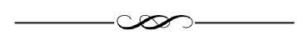

Another insight that emerges as we compare constructive and contentious approaches to transformative change is the essential role that learning and training play in both. Among nonviolent resistance scholars and activists, it is now well understood that contemporary movements can learn from past movements, even as they generate new knowledge and insight within their own social contexts, which can in turn contribute back to the collective store of knowledge that future movements are able to draw on. Indeed, there is an entire academic field now focused on "social movement learning," along with activist journals and websites devoted to this theme. ${ }^{11}$ In addition, it is

10 For evidence of these claims, refer again to Karlberg, "Constructive Resilience."

11 Refer, for instance, to Maria Isabel Casas-Cortés, Michal Osterweil, and Dana Powell, "Blurring Boundaries: Recognizing Knowledge-Practices in the Study of Social Movements"; and Laurence Cox, "Movements Making Knowledge: A New Wave of Inspiration for Sociology?" See also the activist journals Reflections on a Revolution, and Interface: A Journal for and about Social Movements. well understood that movements are most effective when such knowledge is imparted to their participants through systematic forms of training, which mobilize people to take creative initiatives within a shared framework of activism. Again, a growing body of academic and activist literature has been examining this theme. ${ }^{12}$

All these processes could be seen, for instance, when leaders of the U.S. Civil Rights Movement began adapting insights from Gandhi's nonviolent movement in India to their own struggles, even as protagonists of the U.S. struggle continued generating new insights while developing corresponding systems for training movement participants. Today, such processes are playing out globally through myriad movements of nonviolent resistance, linked to a growing body of literature on nonviolent praxis, promulgated through centers of nonviolent training that are multiplying in formal and informal spaces and online settings.

The radical constructive agency of the worldwide Bahá'í community is advancing through a parallel dynamic that intersects with these other processes. Drawing on a century and a half of its own experience, as well as on

12 Refer, for example, to Larry Isaac, Daniel Cornfield, Dennis Dickerson, James Lawson, and Jonathan Coley, "'Movement Schools' and Dialogical Diffusion of Nonviolent Praxis: Nashville Workshops in the Southern Civil Rights Movement"; and Mark Engler and Paul Engler, This Is an Uprising: How Nonviolent Revolt Is Shaping the Twenty-First Century. 
accumulated bodies of knowledge and experience beyond the Bahá'í community, Bahá'ís have developed a network of training institutes in every region of the world that prepare and mobilize people to take creative initiatives within a shared framework of activism. This decentralized system makes available an accumulating global body of experiential knowledge, even as its local participants continually contribute new insights to that growing body of knowledge. In addition, Bahá'ís are increasingly drawing on this body of knowledge as they participate in, and contribute insights to, wider discourses on social change.

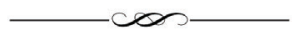

Yet another insight worth noting is the way stories of constructive resilience imbue the concept of "resistance" with new meaning. Within the narrative of contentious agency, resistance is what movement activists engage in, in response to oppressive social forces. But within the narrative of constructive agency, resistance is what the constructive movement encounters from those defending the status quo. In other words, within the latter stories, creative movements for a more just social order are the streams and rivers of historical progress. Those who try to obstruct such currents of progress constitute the resistance-like obstinate stones in the path of a river.

This insight emerged through conversations on constructive resilience at the Highlander Center, alluded to above. The same insight was articulated independently, shortly after that gathering, by Michelle Alexander, a prominent voice in the U.S. struggle for racial justice. In a New York Times opinion piece titled "We Are Not the Resistance," she acknowledges the role of resistance in struggles for social justice, but she cautions, "Resistance is a reactive state of mind. While it can be necessary for survival and to prevent catastrophic harm, it can also tempt us to set our sights too low." Elaborating on this theme, she explains:

Those of us who are committed to the radical evolution of American democracy are not merely resisting an unwanted reality. To the contrary, the struggle for human freedom and dignity extends back centuries and is likely to continue for generations to come. In the words of Vincent Harding, one of the great yet lesser-known heroes of the Black freedom struggle, the long, continuous yearning and reaching toward freedom flows throughout history "like a river, sometimes powerful, tumultuous, and roiling with life; at other times meandering and turgid, covered with the ice and snow of seemingly endless winters, all too often streaked and running with blood." Harding was speaking about Black movements for liberation in America, but the metaphor applies equally well to the global struggle for human dignity and freedom. (Alexander) 
"Every leap forward for American democracy," she continues, "has been traceable to the revolutionary river, not the resistance." "Another world is possible," she concludes, "but we can't achieve it through resistance alone."

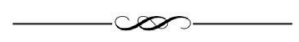

These social dynamics alluded to by Michelle Alexander, above, derive from basic expressions of the human spirit. The aspiration to contribute constructively to the betterment of the world is one of those. So, too, is the quality of resilience in the face of adversity. And we can see both manifest in myriad ways, in countless individuals past and present. In this sense, while constructive resilience can be a characteristic of entire movements, it is also a quality of the individuals who advance those movements. Thus, the story of constructive resilience is also the story of individuals.

I grew up hearing a story about my great-grandmother, Bina Mae Collins, who was born and raised in Springfield, Illinois, in the 1890s. Her father was a coal miner with eleven children, so she did not come from a family of means. She had little formal education. Given that Illinois had only abolished slavery in 1848 , she saw the ongoing violent racism of her times, including a lynching she witnessed as a child and the 1908 massacre of Springfield's Black residents. She married a man who turned out to be a compulsive gambler and, as a result, she struggled to raise her own daughters in conditions of ongoing poverty. She also learned that her husband, like so many White men of his generation, was a closet member of the Ku Klux Klan.

But Bina Mae was a woman of faith whose reading of the Bible centered on living a virtuous life and enacting the social-justice gospel. She sent her husband packing. She opened her home to Black residents of her town. When she traveled south of the Mason-Dixon line, she rode in the back of the bus to express solidarity with Black folk. These were not popular things for a White woman to do at that time. She likely paid a price. Given her hardscrabble background and the many challenges she faced throughout her life, she was clearly a resilient woman.

Bina Mae helped raise my mother and imparted these values to her. When my mother came of age during the turbulent 1960s, she aligned herself with the Civil Rights and Antiwar Movements. While pregnant with me in the late sixties, she began attending meetings to learn about the Bahá'í Faith, which she embraced and told her grandmother about. Upon hearing this, Bina Mae remembered 'Abdu'l-Bahá's visit to Chicago half a century before, in 1912. Bina Mae must have read an article at the time, in an Illinois newspaper, about His visit. 'Abdu'l-Bahá's teachings about the oneness of humanity resonated with her to the extent she would remember His visit so many decades later.

Bina Mae also helped care for me when I was young. She passed away when I was six, and she figures in some of my earliest memories. The stories 
my mother told about her shaped my social imaginary. Along with her resilience, Bina Mae tried to contribute constructively, in the ways she could, to bending the moral arc of the universe toward justice. Her story helped shape my early imagination about who I was and what I could do. The stories of nonviolent social movements I later heard, including my mother's support for those causes, further expanded my imagination, enabling me to envision what was possible through organized collective struggle. The stories of radical constructive agency I have since sought out have further expanded my imagination, enabling me to envision other means of organized collective struggle.

If we hope, one day, to transcend the culture of contest that has been imposed by Western modernity-a culture that has inflicted untold suffering on humanity and is now liquidating the environmental security of future generations - it seems to me that we need to find, tell, and become protagonists in many more stories of radical constructive agency and resilience. To build a new world, we need to expand our constructive imaginary.

\section{Works Cited}

Alexander, Michelle. "We Are Not the Resistance." The New York Times, 21 Sept. 2018. nytimes. com/2018/09/21/opinion/ sunday/resistance-kavanaugh-trump-protest.html.
Boggs, Carl. "Revolutionary Process, Political Strategy, and the Dilemma of Power." Theory and Society, vol. 4, 1977, pp. 359393.

Boyer, Paul. Capturing Education: Envisioning and Building the First Tribal Colleges. Salish Kootenai College P, 2015.

Carroll, Clint. Roots of Our Renewal: Ethnobotany and Cherokee Environmental Governance. U of Minnesota P, 2015.

Casas-Cortés, Maria Isabel, Michal Osterweil, and Dana Powell. "Blurring Boundaries: Recognizing Knowledge-Practices in the Study of Social Movements." Anthropological Quarterly, vol. 8, no. 1, 2008, pp. 17-58.

Chabot, Sean and Stellan Vintagen, "Decolonizing Civil Resistance." Mobilization: An International Quarterly, vol. 2, no. 4, 2015, pp. 517-532.

Cox, Laurence. "Movements Making Knowledge: A New Wave of Inspiration for Sociology?" Sociology, vol. 48, no. 5, 2014, pp. 954-971.

Engler, Mark and Paul Engler. This Is an Uprising: How Nonviolent Revolt Is Shaping the Twenty-First Century. Nation Books, 2016.

Gordon Nembhard, Jessica. Collective Courage: A History of African American Cooperative Economic Thought and Practice. Pennsylvania State UP, 2014. 
Isaac, Larry et al. "'Movement Schools' and Dialogical Diffusion of Nonviolent Praxis: Nashville Workshops in the Southern Civil Rights Movement." Nonviolent Conflict and Resistance: Research in Social Movements, Conflicts and Change, vol. 34, 2012, pp. 155-184.

Karlberg, Michael. Beyond the Culture of Contest: From Adversarialism to Mutualism in an Age of Interdependence. George Ronald, 2004.

___ Constructing Social Reality: An Inquiry into the Normative Foundations of Social Reality. Association for Bahá'í Studies-North America, 2020.

___ . "Constructive Resilience: The Bahá'í Response to Oppression." Peace \& Change, vol. 35, no. 2, 2010, pp. 222-257.

___ . "The Paradox of Protest in a Culture of Contest." Peace \& Change, vol. 28, no. 3, 2003, pp. 319-347.

."Western Liberal Democracy as New World Order?" The Bahá'i World: 2005-2006, edited by Robert Weinberg, Bahá'í World Center Publications, 2007, pp. 133-156.

Mantena, Karuna. "Gandhi and the Means-Ends Question in Politics," Occasional Papers of the School of Social Science, no. 46. https://www.ias.edu/sites/ default/files/sss/papers/paper46.pdf

Schock, Kurt. "The Practice and Study of Civil Resistance." Journal of Peace Research, vol. 50, no. 3, 2013, pp. 277-290.

Sharp, Gene. The Politics of Nonviolent Action. Porter Sargent, 1973.

Sørensen, Majken Jul. "Constructive Resistance: Conceptualizing and Mapping the Terrain," Journal of Resistance Studies, vol. 2, no. 1, 2016, pp. 49-78.

The Universal House of Justice. To the Bahá'í students deprived of access to higher education in Iran, letter dated 9 Sept. 2007. https://www.bahai. org/library/authoritative-texts/the-universal-house-of-justice/messages/20070909_001/1\#018930558

_— - To an individual, letter dated 4 Feb. 2018.

White, Monica. Freedom Farmers: Agricultural Resistance and the Black Freedom Movement. U of North Carolina P, 2018.

Wilson-Raybould, Jody. From Where I Stand: Rebuilding Indigenous Nations for a Stronger Canada. U of British Columbia P, 2019. 